\title{
Pratylenchus neglectus (Nematoda: Pratylenchidae) under the rhizosphere of Brassica napus
}

\author{
S. KUMARI \\ Crop Research Institute, Division of Plant Health, Drnovská 507, Ruzyně, 16106 Prague 6, Czech Republic, \\ E-mail: kumari@vurv.cz
}

\begin{abstract}
Summary
Soil samples under the rhizosphere of Brasicca napus were collected from three localities (Bílé Podolí, Prague, Kylešovice). Two localities Prague and Kylešovice were positive for the presence of Pratylenchus neglectus. The species was identified using morphological features and the morphological identification was verified by using published species-specific primers and by sequencing $18 \mathrm{~S}$ and $28 \mathrm{~S}$ genes of ribosomal DNA.
\end{abstract}

Keywords: Pratylenchus neglectus; PCR; Ribosomal DNA; Czech Republic; Nematode

\section{Introduction}

Root lesion nematodes of the genus Pratylenchus are obligate endoparasites and significant pests in crop cultivation throughout many parts of the world (Nicol et al., 2004; Castillo \& Vovlas, 2008). They are polyphagous in nature and feed on several crops and they can cause substantial yield losses. They feed, molt and reproduce primarily within the plant tissue. All motile stages are capable of feeding from the plant and they are able to move into the soil in search of new roots to invade. The nematode spends most of its time migrating through root tissues destructively feeding on plant cells. They simply suck out the plant cell cytoplasm using its stylet and moving ahead of the lesion. Plants with impaired root branching and cortical degradation caused by lesion nematodes become less capable of extracting nutrients, and water from soil and of yielding as well as healthy plants (Smiley \& Machado, 2009). Root-lesion nematodes reproduce only on living roots of susceptible plant species and, as highly evolved parasites, they do not kill their hosts. These nematodes remain mobile and may move into and out of roots and may deposit eggs in soil as well as within root tissue. They are the second most important plant-parasitic nematodes after root knot nematodes (Jatala \& Bridge, 1990). P. neg- lectus along with $P$. thoreni were associated with reduction of winter wheat and barley yield under field conditions (Taylor et al., 1999; Lasserre et al., 1994; Smiley et al., 2005). Oilseed rape (Brassica napus) is often used as a break crop between cereal crops and in vitro tests of Pratylenchus on rape cultivar has shown that rape cultivar could be damaged by Pratylenchus from preceding cereal crop (Webb, 1990; Webb, 1996).

Morphological identification of Pratylenchus nematodes requires examination of several adult female specimens by an experienced taxonomist. Therefore, a simple, quick, reliable, and relatively inexpensive diagnostic DNA-based techniques have been developed to discriminate among different species of Pratylenchus (Al-Banna et al., 2004; Yan et al., 2008). The objective of this study was to describe Pratylenchus neglectus morphologically and verify their morphological identification by using published species-specific primers and by sequencing.

\section{Materials and methods}

The occurrence of Pratylenchus neglectus (Rensch 1924) Filipjev and Schuurmans Stekhoven 1941 associated with Brassica napus was examined from three localities (Bílé podolí, Prague, Kylešovice) in the Czech Republic. Pratylenchus was found in two localities Prague and Kylešovice Specimens for morphological and molecular analysis from the soil were extracted by Baermann funnel method. Small amount of soil $(25-50 \mathrm{~g})$ was placed on a tissue paper on a Baermann funnel for $24-48$ hours. Nematodes for morphological study were heat killed, fixed in $\mathrm{TAF}$, processed in slow glycerin process and mounted in anhydrous glycerin on slides. Photomicrographs were recorded with a digital camera linked to a computer and measurements were made with the aid of imaging software (Olympus DP-soft).

For specific amplification of P. neglectus two set of pri- 


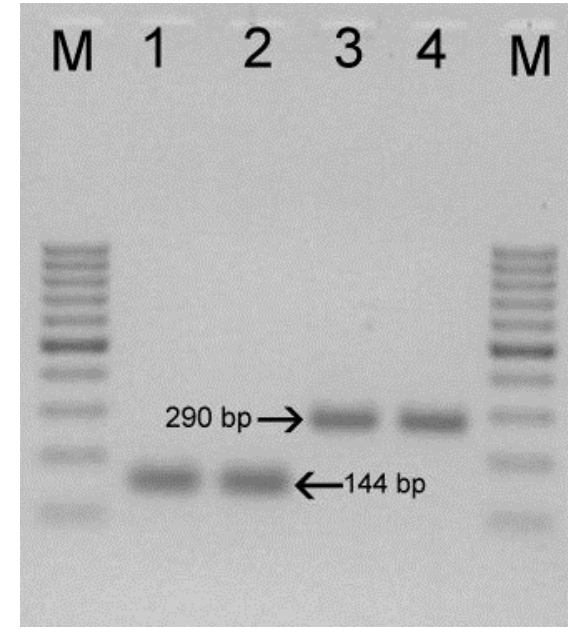

Fig. 1. Electrophoresis of the amplified products from single individuals of Pratylenchus neglectus: lane M - 100 bp DNA ladder (Fermentas); lane 1 and 2 with primers PNEG_F1+D3B5; lane 3 and 4 with primers PNEG+D3B

mers were used. Species-specific sense primers for first set was PNEG-F1 (5'-CGC AAT GAA AGT GAA CAA TGT C $-3^{\prime}$ ) and antisense D3B5 (5'-AGT TCA CCA TCT TTC GGG TC-3') (Yan et al., 2008). Species-specific sense primers for the second set was PNEG (5'-ATG AAA GTG AAC ATG TCC TC -3') and antisense D3B (5'-TCG GAA GGA ACC AGC TAC TA-3') (Al-Banna et al., 2004). Total genomic DNA was extracted from single individuals with a rapid technique (Stanton et al., 1998). The PCR was performed in a $25 \mu 1$ total volume containing 1 PCR bead (GE Healthcare, Buckinghamshire, UK), $20.5 \mu$ l double distilled sterile water, $2.0 \mu \mathrm{l}$ each primer $(10 \mathrm{pmol} / \mu \mathrm{l})$ (synthesized by Generi Biotech, Hradec Králové, Czech Republic), and to this $0.5 \mu$ l of DNA was added as a template for PCR. A negative control (sterilized water) was included in all PCR experiments. All PCR reactions were performed on a DNA Engine PTC-1148 thermal cycler (Bio-Rad). The DNA was subjected to a PCR with the following specifications: first denaturation for $3 \mathrm{~min}$ at $95^{\circ} \mathrm{C}, 41$ cycles with $30 \mathrm{~s}$ at $95^{\circ} \mathrm{C}, 30 \mathrm{~s}$ at $62^{\circ} \mathrm{C}, 30 \mathrm{~s}$ at $72^{\circ} \mathrm{C}$ and final extension at $72^{\circ} \mathrm{C}$ for $10 \mathrm{~min}$. For both primer sets annealing temperature used was $62^{\circ} \mathrm{C}$. An aliquot $(8 \mu \mathrm{l})$ of each amplification reaction was mixed with $2.0 \mu \mathrm{l}$ of $6 \mathrm{x}$ loading dye (Fermentas, MBI) and electrophoresed in high resolution $1.5 \%$ agarose gel and run in TAE (Tris-Acetate-EDTA) buffer. The bands were visualized and photographed under UV (312 nm) after syber safe ( $1 \mu \mathrm{g} / \mathrm{ml}$ ) binding to the DNA fragments. A 100 base pair marker (Fermentas) was included on gel.

Few alive specimens were preserved in $\mathrm{IM} \mathrm{NaCl}$ for sequencing. Temporary mounts of four individual nematodes from two populations were made in a droop of $\mathrm{IM} \mathrm{NaCl}$ containing glass beads and after taking photomicrographs the slides were dismantled, individual nematodes removed, and added to digest in $0.25 \mathrm{M} \mathrm{NaOH}$ overnight. Total genomic DNA was extracted as described above. $18 \mathrm{~S}$ gene of ribosomal DNA was amplified in two overlapping fragments and primer combination was $988 \mathrm{~F}+1912 \mathrm{R}$ for the first fragment and $1813 \mathrm{~F}+2646 \mathrm{R}$ for the second fragment (Holterman et al., 2006). D2/D3 expansion segments of $28 \mathrm{~S}$ gene were amplified using D2A and D3B primers (De Ley et al., 1999). PCR reactions were performed as described above. The cycling conditions were: first denaturation for $3 \mathrm{~min}$ at $94^{\circ} \mathrm{C}, 40$ cycles with $30 \mathrm{~s}$ at $94^{\circ} \mathrm{C}, 30 \mathrm{~s}$ at $55^{\circ} \mathrm{C}, 30 \mathrm{~s}$ at $72^{\circ} \mathrm{C}$ and a final elongation step was run at $72^{\circ} \mathrm{C}$ for $10 \mathrm{~min}$. DNA was purified using High Pure Product Purification kit (Roche Diagnostics GmbH, Manheim, Germany) and directly sequenced in both directions (Macrogen, Korea). Sequencher ${ }^{\mathrm{TM}} 4.8$ (Genes Codes. Corp., Ann Arbor, MI, USA) software was used to assemble and view sequences and check for base-calling errors. These four specimens for sequencing were also amplified with the both sets of species-specific primers.

\section{Results and Discussion}

Morphometrics of females are presented in Table 1. Females characterized by great variation in body length, width and tail shape. Body slightly curved ventrally when killed by gentle heat. Cutilce with fine annulations; lateral field with four incisures. Cephalic region low and flattened with massive sclerotization. Robust stylet with round, anteriorly flat or indented basal knobs. Median bulb oval to round very muscular. Female monodelphic, with anterior ovary functional. Postvulval uterine sac present. Vulav in posterior region. Tail variable in shape, conoid to subcylindroid. Males were not found.

Table 1. Morphometrics of females of Pratylenchus neglectus (Rensch 1924) Filipjev and Schuurmans Stekhoven 1941. Measurements in $\mu \mathrm{m}$ (in form): mean \pm standard deviation (range).

\begin{tabular}{|c|c|c|}
\hline $\begin{array}{l}\text { Locality } \\
\mathrm{n}\end{array}$ & $\begin{array}{c}\text { Prague } \\
9 \\
\end{array}$ & $\begin{array}{c}\text { Kylešovice } \\
8 \\
\end{array}$ \\
\hline $\bar{L}$ & $\begin{array}{c}435 \pm 78 \\
(307-552)\end{array}$ & $\begin{array}{c}410 \pm 38 \\
(371-475)\end{array}$ \\
\hline $\mathrm{a}$ & $\begin{array}{c}26.1 \pm 6.20 \\
(15.4-36.8)\end{array}$ & $\begin{array}{c}22.6 \pm 2.29 \\
(19.4-26.2)\end{array}$ \\
\hline $\mathrm{b}$ & $\begin{array}{l}4.2 \pm 0.39 \\
(3.7-5.0)\end{array}$ & $\begin{array}{l}4.1 \pm 0.35 \\
(3.6-4.6)\end{array}$ \\
\hline $\mathrm{c}$ & $\begin{array}{c}21.5 \pm 3.84 \\
(12.3-25.0)\end{array}$ & $\begin{array}{c}18.8 \pm 3.02 \\
(14.4-24.0)\end{array}$ \\
\hline $\mathrm{c}^{\prime}$ & $\begin{array}{c}2.06 \pm 0.39 \\
(1.43-2.67)\end{array}$ & $\begin{array}{c}1.96 \pm 0.34 \\
(1.45-2.45)\end{array}$ \\
\hline vulva & $\begin{array}{l}82 \pm 1.96 \\
(79-86)\end{array}$ & $\begin{array}{l}81 \pm 1.40 \\
(79-83)\end{array}$ \\
\hline stylet & $\begin{array}{l}21 \pm 3.32 \\
(13-17)\end{array}$ & $\begin{array}{l}15 \pm 1.07 \\
(14-17)\end{array}$ \\
\hline Tail length & $\begin{array}{l}21 \pm 3.32 \\
(16-25)\end{array}$ & $\begin{array}{l}22 \pm 3.88 \\
(16-28)\end{array}$ \\
\hline $\begin{array}{l}\text { Body diameter } \\
\text { at lip region }\end{array}$ & $\begin{array}{c}8 \pm 0.83 \\
(7-9)\end{array}$ & $\begin{array}{c}8 \pm 0.64 \\
(7-9)\end{array}$ \\
\hline at mid body & $\begin{array}{l}17 \pm 3.26 \\
(14-24)\end{array}$ & $\begin{array}{l}18 \pm 1.83 \\
(16-21)\end{array}$ \\
\hline at anus & $\begin{array}{c}10 \pm 1.62 \\
(9-14) \\
\end{array}$ & $\begin{array}{l}11 \pm 1.19 \\
(10-13)\end{array}$ \\
\hline
\end{tabular}




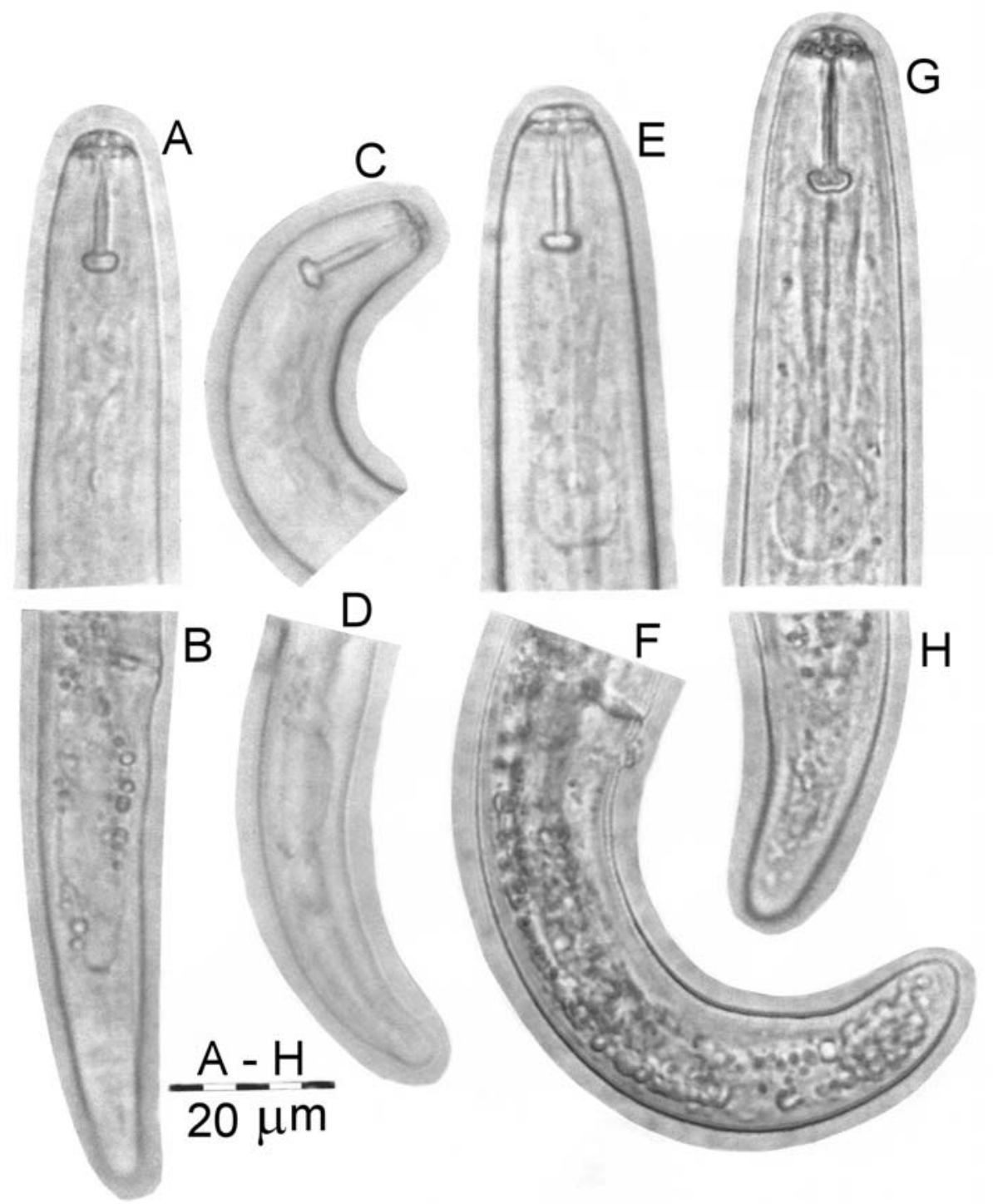

Fig. 2. Anterior and posterior regions of specimens from locality Prague (A - D) and Kylešovice (E - H) used for sequencing. A, B: Female; C, D: Juvenile; E, F: First female; G, H: Second female

Morphometrics of females of $P$. neglectus from two localities are similar to each other. Morphometrics of females are also within the minimum and maximum ranges given by Andrásy (2007) except radio 'b' which is shorter in both Czech populations. Morphological identification of both populations was reliably verified by PCR using two sets of published primers of ribosomal DNA (Al-Banna et al.; 2004, Yan et al., 2008). A single fragment of approximately $144 \mathrm{bp}$ was amplified for all studied individuals with primers PNEG-F1+D3B5 and 299 bp with primers PNEG+D3B (Fig. 1). No PCR products were obtained in the negative control lacking DNA template or in the negative control containing DNA of Aphelenchoides, Aphelenchus, Bitylenchus, Boleodorus, Helicotylenchus, Merilinus, Trophurus and Tylenchus.

Photomicrographs of four individual (two per populations) used for sequencing $28 \mathrm{~S}$ and $18 \mathrm{~S}$ genes of ribosomal DNA are given in Fig. 2. These four specimens were also posi- tive with the both sets of species-specific primers. Identical sequences were obtained from four individuals. The representative sequences were deposited in National Center for Biotechnology Information (NCBI) and their accession numbers are JQ303332 (18S gene) and JQ303333 (28S expansion segments). The obtained sequences were compared by Basic Local Alignment Search Tool (BLAST) and the first top hit of $18 \mathrm{~S}$ sequence showed 1673/1676 nucleotides identity to $P$. neglectus accession number EU669923 (Holterman et al., 2009) and 28S gene showed $648 / 656$ identities also to $P$. neglectus accession number EU130854 (Subbotin et al., 2008).

\section{Acknowledgements}

The work was supported by the Ministry of Agriculture of the Czech Republic, Project number MZe-0002700604 etapa 08 . 


\section{References}

Al-Banna, L., Ploeg, A. T., Williamson, V. M., KAlOSHIAN, I. (2004): Discrimination of six Pratylenchus species using PCR and species-specific primers. J. Nematol., 36: $142-146$

ANDRÁSY, I. (2007): Free-living nematodes of hungary (Nematoda Errantia). II. Pedozoologica Hungarica, Budapest.

Castillo, P., Vovlas, N. (2008): Pratylenchus (Nematoda, Pratylenchidae): Diagnosis, biology, pathogenicity and management. Nematol. Monogr. Perspect., 6: 1 - 530

De Ley, P., FéliX, M. A., Frisse, L. M., NAdler, S. A., SternberG, P. W., Thomas, W. K. (1999): Molecular and morphological characterisation of two reproductively isolated species with mirror-image anatomy (Nematoda: Cephalobidae). Nematology, 1: $591-612$

Holterman, M., Karssen, G., VAn den Elsen, S., VAN MEGEN, H., BAKKER, J., HELDER, J. (2009): Small subunit rDNA-based phylogeny of the Tylenchida sheds light on relationships among some high-impact plant-parasitic nematodes and the evolution of plant feeding. Phytopathology, 99: 227 - 235. DOI: 10.1094/PHYTO-99-3-0227 Holterman, M., van DER WurfF, A., VAN DEN Elsen, S., VAn Megen, H., Bongers, T., HolOvachov, O., BAKKer, J., HeLDER, J. (2006): Phylum-wide analysis of SSU rDNA reveals deep phylogenetic relationships among nematodes and accelerated evolution toward crown clades. Mol. Biol. Evol., 23: 1792 - 1800. DOI: 10.1093/molbev/mls044

JATALA, P., BRIDGE, J. (1990): Nematode parasites of root and tuber crops. In: Luc, M., Sikora, R. A., and Bridge, J. (eds), Plant parasitic nematodes in subtropical and tropical agriculture, $137-180$. CABI, Wallingford, UK.

LASSERRE, F., R. RIVOAL, R. COOK (1994): Interactions between Heterodera avenae and Pratylenchus neglectus on wheat. J. Nematol., 26: 336 - 344

NiCOL, J., R. RivOAL, S. TAYLOR, M. ZAHARIEVA (2004): Global importance of cyst (Heterodera spp.) and lesion nematodes (Pratylenchus spp.) on cereals: distribution, yield loss, use of host resistance and integration of molecular tools. Nematol. Monogr. Perspect., 2, 233 - 251.

Smiley, R. W., MachadO, S. (2009): Pratylenchus neglectus reduces yield of winter wheat in dryland cropping systems. Plant Dis., 93: 263 - 271. DOI: 10.1094/PDIS93-3-0263

Smiley, R. W., Whittaker, R. G., Gourlie, J. A., EASLEY, S. A. (2005): Suppression of wheat growth and yield by Pratylenchus neglectus in the Pacific Northwest. Plant Dis., 89: 958 - 968. DOI: 10.1094/PD-89-0958

Stanton, J. M., McNicol, C. D., Steele, V. (1998): Non-manual lysis of second-stage Meloidogyne juveniles for identification of pure and mixed samples based on the polymerase chain reaction. Australas. Plant Path., 27: 112 - 115. DOI: 10.1071/AP98014

Subbotin, S. A., Ragsdale, E .J., Mullens, T., Roberts, P. A., Mundo-OcAmpo, M., Baldwin, J. G. (2008): A phylogenetic framework for root lesion nematodes of the genus Pratylenchus (Nematoda): Evidence from $18 \mathrm{~S}$ and D2-D3 expansion segments of 28S ribosomal RNA genes and morphological characters. Mol. Phylogenet. Evol., 48: 491 - 505. DOI: 10.1016/j.ympev.2008.04.028

TAYlor, S. P., VAnstone, V. A., Ware, A. H., McKay, A. C., SzOT, D., Russ, M. H. (1999): Measuring yield loss in cereals caused by root lesion nematodes (Pratylenchus neglectus and $P$. thornei) with and without nematicide. Aust. J. Agric. Res., 50: 617 - 622. DOI: 10.1071/A98103 WEBB, R. M. (1990): Effects of the nematode Pratylenchus fallax on roots of oilseed rape (Brassica napus var. oleifera). Rev. Nématol., 13: $115-117$

WeBB, R. M. (1996): In vitro studies of six species of Pratylenchus (Nematoda: Pratylenchidae) on four cultivars of oilseep rape (Brassica napus var. oleifera). Nematologica, 42: $89-95$

Yan, G. P., Smiley, R. W., OKubara, P. A., Skantar, A., EAsley, S. A., Sheedy, J. G., ThOMPSON, A. L (2008): Detection and discrimination of Pratylenchus neglectus and P. thornei in DNA extracts from soil. Plant Dis., 92: 1480 - 1487. DOI: 10.1094/PDIS-92-11-1480 